\title{
EMPLOYEE BENEFITS OR WAGE INCREASE?
}

\author{
J. Duda
}

Received: December 17, 2010

\begin{abstract}
DUDA,J.: Employee benefits or wage increase? Acta univ. agric. et silvic. Mendel. Brun., 2011, LIX, No. 2, pp. $65-68$

The paper comes from a survey done during the years 2007-2009. It focused on employee satisfaction with the provision of employee benefits. The research included 21 companies, 7 companies were from the engineering sector, 7 companies from the food industry, 3 companies represented the budgetary sphere, 3 companies the services sector and one company operates in pharmaceutical industry. The questionnaire survey consisted of 14 questions, including 5 identification-questions. The paper presents results of the questions on dealing with employees' awareness of employee benefits and on choosing between employees' preferences of wage increase or increase in value of benefits provided. Employees are informed about all options of providing employee benefits. Only in 3 cases employees stated dissatisfaction with information. This answer was related with the responses to the second monitored question. Employees of these companies preferred pay increases before benefits' increases. There was no effect of gender of the respondents, neither the influence of the sector of operation, in the preference of increases in wages or in benefits. Exceptions were the employees of companies operating in the financial sector, who preferred employee benefits before a wage increase. It was found that employees of companies who participated in research in 2009, preferred wage increases before the extension of employee benefits, although the value of the net wage increase is lower than the monetary value of benefits increase.

The paper is a part of solution of the research plan MSM 6215648904 The Czech economy in the process of integration and globalization, and the development of agricultural sector and the sector of services under the new conditions of the integrated European market.
\end{abstract}

employee benefit, questionnaire survey, wage increase

In most European countries there are a number of legal provisions on social and health insurance, holidays, length of employment, normal physical parameters of work, recruitment levels, etc. Therefore, this group of factors can be an effective stimulus is legally guaranteed to all employers. Social systems (employee benefit) advantages used by the company are oriented in the direction of the so-called above standard. A range of indirect compensation, employee benefits depends primarily on the capital strength of the company, history and culture of the region, company philosophy and organizational culture of the company (Pražská, Jindra, 2006).

This paper aims to present the results of the author's long-term survey to employee satisfaction with the provision of employee benefits, focusing on awareness of the employers on the issue of em- ployee benefits and employees' preferences determine the choice of a wage increase or increase in value of employee benefits provided by the same amount.

\section{MATERIALS AND METHODS}

During the years 2007-2009 were carried out questionnaire surveys dealing with employee satisfaction with employee benefits provided by $21 \mathrm{com}-$ panies, 7 companies were from the engineering sector, seven companies from the food industry, three companies represented the budgetary sphere, 3 companies in the services sector and one company operates in the pharmaceutical industry. It used a questionnaire to the author (Duda, 2004). Square contingency statistical method was used for the processing of survey results (Stávková, 2004). 


\section{RESULTS AND DISCUSSION}

If an organization wants to employee benefits have a positive impact on staff motivation, satisfaction and stability, should be wondering whether they were employees with employee benefits offered sufficiently familiar. Experience shows that companies often offer a large amount of employee benefits, but their employees often have little idea of what to expect. Also, the fact that employees understand the various components of employee benefits and understand their value is the main reason why they are with them unhappy. For the above reasons, it is therefore essential that businesses and their employees clearly informed clearly about our employee benefits. The basic prerequisite for providing employee benefits management is participation of the employees in the process of their choice. The result is an understanding to provided employee benefits and perhaps making them more satisfaction with these benefits (Milkovich, Boudreau, 1993). Employees may choose the appropriate employee benefits only if they have adequate information and are carefully evaluate their needs. Awareness of employee benefits will increase when the written form of information sent to each worker distinctly. It is also appropriate to use the meeting, conveniently located prominent posters, corporate radio, etc. (Koubek, 2007).

Currently, the use of Internet and computer technology is information most commonly performed using intranet sites, e-mail messages, especially if the company has introduced the so-called cafeteria system, an optional system of providing employee benefits.

One question survey employee satisfaction mapping was focused on the awareness of employees about the offer employee benefits. The results showed that employees are informed of the offer provided benefits, mostly for two-thirds of respondents satisfied with information (across sectors surveyed). Dissatisfaction with information stated employee only in 3 cases (companies). This ignorance was related to the results of responses to the second question followed, dealing with the increasing preference of the gross wages or increase the value of employee benefits. Employees of these companies preferred to wages increases. The survey of satisfaction with the provision of employee benefits to employees of the firms were asked whether they prefer a wage increase before the extension of employee benefits at the same level with the addition of the wage increase in "clean" will be worth less money than the value of employee benefits because employee must pay tax, social and health insurance.

The answers to this question confirmed as a major force in wage incentive factor. Although financial terms are more favourable to draw wage than employee benefits (certain employee benefits are taxexempt income and are exempt from payment of social and health insurance), many respondents staff from monitored companies would prefer an increase in gross wages (from which the employee must pay social and health insurance and pay income tax) before extending employee benefits to same nominal amount.

Although the overall results are not apparent preference of wage increases can be seen on the results of partial dominance preferences to wage increase. If the employees in individual companies prefer wage, mostly it was a high percentage of wages to the preferences menu of employee benefits. If the employees of the company preferred to extend employee benefits, often it was a slightly increased preference for employee benefits over salary. The effect of respondents' answers, depending on the jurisdiction of the sector, only for employees of enterprises engaged in services can be stated that there was a high incidence of employee benefits extension preferences. In the companies involved in engineering we can be seen the dominant wage increase. In contrast, firms operating in the food industry have not found the influence of industry, the employees of two companies preferred to wage increase, employees of two firms would prefer the extension of benefits provided and employees of three companies were the equilibrium responses.

A possible explanation for wage increases preference is that the increased wage effect gives immediate financial and employee benefits (such as contribution to pension insurance or life insurance), although in the higher fair value is often tied to a time period when the amount of financial handle. Salary is claimed component of remuneration, employee benefits are often embedded in the collective agreement or an internal regulation, but the economic difficulties of the company are often in agreement with labour unions (where the company operates) restricted or abolished.

The influence of the crisis is likely to observe the responses of employees of companies who participated in research in 2009. With the exception of one company employee remaining five companies (mainly engineering) preferred the possibility of increasing the gross earnings from the potential expansion track of employee benefits. These responses confirm a possible explanation of preference wages (wages that are less favourable) before offering employee benefits that are described in this paper.

The benefits of providing employee benefits against the provision of monetary contributions to the wages increase we can be demonstrated in the following model example to use a food allowance provided in the form of vouchers.

Parameters model:

- basic monthly gross wage: 24000 CZK per month, - the value of the vouchers CZK 90,

- 20 working days.

Comparison of net income and expenditure of the employer and employee, if:

- employer wage employees increased gross amount of $990 \mathrm{CZK}$ 
- employer decided to provide vouchers to post for maximum tax savings (55\%), ie $990 \mathrm{CZK}$.

Assuming that employees provide maximum performance for vouchers, there are (see tab.I.) to reduce the monthly cost of the employer to an employee in CZK 337 CZK, caused by lower social and health insurance. If the employee takes full advantage offered vouchers, increases his net monthly income of $310 \mathrm{CZK}$.

A similar result can be achieved in the provision of pension or life insurance, where the tax optimum is also a monthly contribution of CZK 1000 . You can see that the provision of employee benefits of compensation for the increase in gross wages leads to financial savings for both the employer and the employee. The examples above advantages claim that it is preferable to provide to employee benefit, instead of simply an increase in gross wages. If the employer decides to provide the above benefits before increased wages and for maximum utilization of the tax effect of the employer to reduce its annual costs by about 10000 CZK. Providing employee benefits is advantageous for employees. Disadvantage may be that the financial benefits the employee no receives his wages directly, but their pension insurance and life insurance, or the value of vouchers.

The advantage of employee benefits depends on the fiscal policies of the state. Examples include contributions to pension and life insurance, which, if not tax advantaged in society often been used as employee benefits. Changes in tax laws and the possibility to include these contributions into tax deductible expenses, these contributions became most commonly provided employee benefits.

This solution can be used in ever-increasing demands on employees' wage increases given the opportunity to increase net wage by employee benefits. An important and integral part of successful negotiations is a thorough explanation of the advantages of the use of employee benefits compared to an increase in gross wages.

\section{I: Comparison of the advantages of providing vouchers}

\begin{tabular}{|c|c|c|c|}
\hline & Wage & Salary + cash prize & Salary + vouchers \\
\hline Number of days worked & & & 20 \\
\hline The nominal value of the vouchers & & & $90 \mathrm{CZK}$ \\
\hline The value of financial rewards / vouchers (55\%) & & $990 \mathrm{CZK}$ & $990 \mathrm{CZK}$ \\
\hline Gross wages & $24000 \mathrm{CZK}$ & $24990 \mathrm{CZK}$ & $24000 \mathrm{CZK}$ \\
\hline Social insurance - employee & $1560 \mathrm{CZK}$ & 1624 CZK & $1560 \mathrm{CZK}$ \\
\hline Health insurance - employee & $1080 \mathrm{CZK}$ & $1125 \mathrm{CZK}$ & $1080 \mathrm{CZK}$ \\
\hline Social insurance - employer & $6000 \mathrm{CZK}$ & $6248 \mathrm{CZK}$ & $6000 \mathrm{CZK}$ \\
\hline Health insurance - employer & $2160 \mathrm{CZK}$ & $2249 \mathrm{CZK}$ & $2160 \mathrm{CZK}$ \\
\hline Taxable & $32160 \mathrm{CZK}$ & 33487 CZK & $32160 \mathrm{CZK}$ \\
\hline Pre-tax & $4824 \mathrm{CZK}$ & $5025 \mathrm{CZK}$ & $4824 \mathrm{CZK}$ \\
\hline Tax relief & $2070 \mathrm{CZK}$ & $2070 \mathrm{CZK}$ & $2070 \mathrm{CZK}$ \\
\hline Net wages & $18606 \mathrm{CZK}$ & $19286 \mathrm{CZK}$ & $19596 \mathrm{CZK}$ \\
\hline
\end{tabular}

Source: Sodexho, 2010

\section{SUMMARY}

The paper comes from a survey done during the years 2007-2009. It focused on employee satisfaction with the provision of employee benefits. The research included 21 companies, 7 companies were from the engineering sector, 7 companies from the food industry, 3 companies represented the budgetary sphere, 3 companies the services sector and one company operates in pharmaceutical industry. The questionnaire survey consisted of 14 questions, including 5 identification-questions. The paper presents results of the questions on dealing with employees' awareness of employee benefits and on choosing between employees preferences of wage increase or increase in value of benefits provided. Employees are informed about all options of providing employee benefits. Only in 3 cases employees stated dissatisfaction with information. This answer was related with the responses to the second monitored question. Employees of these companies preferred pay increases before benefits increases. There was no effect of gender of the respondents, neither the influence of the sector of operation, in the preference of increases in wages or in benefits. Exceptions were the employees of companies operating in the financial sector, who preferred employee benefits before a wage increase. It was found that employees of companies who participated in research in 2009, preferred wage increases before the extension of employee benefits, although the value of the net wage increase is lower than the monetary value of benefits increase. 


\section{REFERENCES}

DUDA, J, 2004: Zaměstnanecké výhody v systému rízení lidských zdrojui. Disertační práce. Brno: MZLU v Brně. $158 \mathrm{~s}$.

KOUBEK, J., 2007: Řízenílidskýchzdrojü. 4. vyd. Praha: ManagementPress.400s.ISBN 978-80-7261-168-3. MILKOVICH, G. T. and BOUDREAU, J. W, 1993: Řízenílidských zdrojů. 1. vyd. Praha: Grada a. s. 936 s. ISBN 80-85623-29-3.

PRAŽSKÁ, L., JINDRA, J. et al., 2006: Obchodní podnikání. Retail management. 2. vyd. Praha: Management Press. 876 s. ISBN 80-7261-059-7.
SODEXO, 2010: Kalkulačka výhodnosti při použití stravenek Gastro Pass. [online]. [cit. 2010-0917]. Dostupné z: http://www.sodexo.cz/czcz/ nase-sluzby/zamestnanecke-vyhody-darky/ informace-pro/zamestnavatele/kolik-usetrite/kalkulacka-vyhodnosti-stravenky-gastropass.asp?t_phm $=24000 \& t_{-}$vo $=90 \& t_{-}$ps $=20 \& t_{-}$ $\mathrm{pz}=1 \& \mathrm{x}=54 \& \mathrm{y}=9 \& \mathrm{~h} \_$postback $=1$.

STÁVKOVÁJ., DUFEK, J., 2004: Marketingový výzkum. 2. vyd. Brno: MZLU v Brně. 191 s. ISBN 80-7157$795-2$.

Address

Ing. Jiří Duda, Ph.D., Ústav managementu, Mendelova univerzita v Brně, Zemědělská 1, 61300 Brno, Česká republika, e-mail:duda@mendelu.cz 